\title{
Impact of the activities of tour operators destabilizing changes in tourist destinations and ecotourism as a factor to minimize them
}

\author{
Illia Pysarevskyi ${ }^{1}$, Larysa Obolentseva ${ }^{1}$, Iryna Polchaninova ${ }^{1}$, Oksana Kharchenko ${ }^{1}$, and \\ Olena Uhodnikova ${ }^{1, *}$ \\ ${ }^{1}$ O.M. Beketov Kharkiv National University of Urban Economy, Marshala Bazhanova Str. 17, 61002, \\ Kharkiv, Ukraine
}

\begin{abstract}
The article discusses the issues of incorporating external risk factors into the detail of tour operators. The purpose of the article is to investigate the redistribution of tourist flows under the influence of natural and man-made factors, in particular, plane crashes, terrorist attacks, political events, earthquakes, fires, floods, hurricanes and more. The article contains an analysis of the following aspects: transport services; services that ensure the comfort of stay of tourists outside of permanent residence (food, freedom of communication, accommodation, etc.); services that of the tourist may need while staying on a one-time of tourist the trip (treatment, entertainment, souvenirs, etc.). The author proposes a mechanism for predicting the volume of tourist flows based on the use of mathematical modeling, which will allow to take into account the scale of the crisis, its terms, development and distribution in order to improve the activities of the crisis in the event of crisis caused by natural and technological factors in one or another tourist direction and ensuring their stable functioning under conditions of destabilizing factors. It is proposed to consider ecological tourism as a factor in minimizing the negative effects of human impact on the environment and reducing man-made impact.
\end{abstract}

\section{Introduction}

The intensification of competition in the global market requires all its subjects to maximize the effective use of their own resource potential in a rational combination with external conditions of operation. The tourism sector, whose effectiveness of economic activity and ensuring of harmonious development are directly dependent on external cooperation, does not remain aloof. The development of the tourism business is quite important for any country in the world, because:

- Firstly, it contributes to the infrastructural development of the territories and the employment rate of the local population;

\footnotetext{
*Corresponding author: ugodnikova16@gmail.com
} 
- Secondly, it allows the use of geographical, climatic, natural and recreational resources not used in other spheres of economic activity;

- Thirdly, it provides stable both foreign exchange earnings (in the case of external tourism) and cash flows in national currency (domestic tourism) to budgets of different levels.

The development of the tourism sector depends mainly on the directions of tourist flows that are formed under the influence of demand for tourist services of a country in the world. At the same time, it should be noted that tourist demand is a rather specific phenomenon, which depends as much as possible on individual types of demand for various material goods and services, the most important of which are:

- Transport services;

- Services that ensure the comfort of stay of tourists outside of permanent residence (food, freedom of communication, accommodation, etc.);

- Services that of the tourist may need while staying on a one-time of tourist the trip (treatment, entertainment, souvenirs, etc.).

However, in our opinion, the demand for tourism services depends to a large extent not only on infrastructure factors, but also on changes in the conditions of stay of tourists outside the permanent residence under the influence of destabilizing changes in the environment.

\section{Analysis of the Latest Researches and Publications}

First of all, it should be noted that the tourism sector in the research of scientists is considered in most cases from the standpoint of ensuring its development and attractiveness. Thus, in the works of O. Komlichenko [1], V. Patsyuk [2], O. Chechens [3], I. Temnik [4], I. Kovtunik [5], these are some aspects of tourism development. For example, O. Komlichenko, based on the results of studies of A. Azaryan and N. Zhukov [6], L. Dyadechko [7], M. Zhukov [8], S. Tsekhla [9], proposes the author's classification of factors influencing the development of tourism sphere [1], and concludes that it is advisable to systematize and classify these factors in order to form a state policy for regulating the functioning of the tourism industry [1]. O. Chechnya's research also aims to identify and classify the factors influencing tourism. In particular, the author proposes his own classification of these factors and concludes that "... the use of the proposed classification will allow to group of the factors and reveal their impact on the industry, regulate the dynamics and direction of development of the tourism industry" [3]. V. Patsyuk considers the factors of development of tourist industry of industrial city. The author notes that "... any point and place of the globe can become an object of tourism when the stimulating factors are activated" [2], which confirms the fact of change of directions of tourist flows.

Studies by I. Temnik and I. Kovtunik are aimed at determining the factors of international tourism development. Thus, I. Temnyk emphasizes that "... for the development of international tourism in a certain country, first of all, such conditions as a favorable climate are needed; natural, historical and cultural heritage; advanced hotel and related industries; high level of security, including from international terrorism; price availability of tourist services; developed system of sports entertainment and active activity of friendly local organizations» [4]. I. Kovtunyk notes that “... for the development of international tourism, the necessary conditions and a developed material and technical base are necessary" [5]. At the same time, the author emphasizes the importance of such factors as the state of the legal base of regulation of the sphere of international tourism in the country, tendencies of the business environment and development of tourist infrastructure, resource potential in ensuring the competitiveness of the national tourism industry in the global tourism market. 
Instead, the study of the directions of tourist flows, the principles and methods of their formation and the factors influencing their functioning are quite small. In particular, it is advisable to highlight the works of B. Koshova [10], K. Kucherenko [11], V. Druzhinina, G. Lutsenko, and A. Ryzhak [12], I. Pisarevsky, I. Polchaninova, T. Malysheva, S. Pogasy, M. Pokolodnaya [13-14]. Thus, B. Koshova notes that “... the dynamics of tourist flows, especially the share of foreign tourists in the total volume, has been declining in recent years" [10]. However, the above trends are only related to the unsatisfactory condition of the tourist infrastructure. K. Kucherenko, exploring the impact of global risk factors on the process of forming an international tourism brand, emphasizes that "... the main issues that concern tourists in the process of determining their country of travel are those that can be attributed to the overall image of the state (cultural level, environmental situation, criminogenic situation, national and religious tolerance, political and economic stability), as well as those related to the development of tourist infrastructure (availability of recreational resources and comfort of rest, co burden of price level of service, security, travel, luggage integrity, etc.) "[11]. Later, the author concludes that the directions of tourist flows depend on the awareness of the potential tourist about the country of travel, which in most cases is formed by the influence of information in the media and the responses of other tourists, subconsciously formed stereotypes, which are not always true. In the study of V. Druzhinina, G. Lutsenko and A. Ryzhak an econometric analysis of the factors influencing the tourist flows of the region is carried out. The authors note that quantitatively tourist of flows correlate with domestic regional product, average monthly wage, number of economically active population, dollar exchange rate and consumer price index for goods and services [12].

\section{Purposes and Objectives}

Numerous achievements of scientists do not fully reveal the problem of redistribution of directions of tourist flows under the influence of natural and man-made factors, which is very relevant at the moment, taking into account recent events at popular world resorts.

That is why the purpose of the article is to investigate the redistribution of tourist flows under the influence of natural and man-made factors, in particular, plane crashes, terrorist attacks, political events, earthquakes, fires, floods, hurricanes and more.

\section{Statement of Basic Materials}

The tourism industry holds a dominant position in the economy of many countries, as it is a powerful source of financial income and has a significant synergistic effect in combination with other sectors of the national economy. In light of the increasing terrorist threats, the destabilization of the political environment, the emergence of military conflicts and the occurrence of force-majeure natural and climatic events, it is necessary to study their influence on changing directions of tourist flows, which is reflected in Tables 1-4 and in Figs. 1-3.

The problems of becoming a tourist industry of Ukraine are quite relevant today. Analyzing the factors of tourist flows, as well as the experience that Ukraine can take, the problems of ensuring the effective development of the Ukrainian tourist services is market in the context of global transformations of the tourism institute.

In the process of internationalization of economic life and the growing scale and role of international economic relations, the balance of market and state principles in the mechanism of the international market economy sector is inevitably in the interests of the former. Especially significant is this process in the tourism sphere. 
Table 1.Aviation crashes.

\begin{tabular}{|c|c|c|c|c|}
\hline Year & $\begin{array}{l}\text { Location of } \\
\text { the accident }\end{array}$ & $\begin{array}{l}\text { Country "owner" of } \\
\text { transport }\end{array}$ & Cause of accident & $\begin{array}{c}\text { Number of } \\
\text { casualties }\end{array}$ \\
\hline 2019 & Ethiopia & $\begin{array}{c}\text { Ethiopia (Boeing } \\
737)\end{array}$ & Crashes after takeoff near Bishoft (Debre Zate) & 157 \\
\hline 2018 & Indonesia & $\begin{array}{c}\text { Indonesia (Boeing } \\
737 \mathrm{Max})\end{array}$ & $\begin{array}{c}\text { It crashed against the water strike off the west coast of } \\
\text { Java }\end{array}$ & 185 \\
\hline 2018 & Ukraine & $\begin{array}{c}\text { Ukraine } \\
\text { (McDonnell } \\
\text { Douglas MD-83) } \\
\end{array}$ & $\begin{array}{c}\text { During the landing at the airport, it rolled out of the } \\
\text { runway }\end{array}$ & - \\
\hline 2018 & Cuba & Cuba (Boeing 737) & It crashed after takeoff & 104 \\
\hline 2017 & Kirghizia & $\begin{array}{l}\text { Turkey (Boeing- } \\
747 \text { ) }\end{array}$ & $\begin{array}{l}\text { Due to fog, he collapsed while approaching the post, } \\
\text { crashing into houses near Bishkek }\end{array}$ & 37 \\
\hline 2017 & USA & $\begin{array}{l}\text { United States } \\
(\text { Cessna 210) }\end{array}$ & $\begin{array}{l}\text { The plane disappeared from the radar during the flight } \\
\text { from Arizona to Colorado }\end{array}$ & 4 \\
\hline 2016 & Colombia & $\begin{array}{l}\text { Bolivia (Avro RJ- } \\
\quad 85 \text { ) }\end{array}$ & $\begin{array}{l}\text { It fell in the vicinity of Medellin due to lack of fuel. The } \\
\text { players and employees of the Brazilian club } \\
\text { "Shapekojense" were on board }\end{array}$ & 75 \\
\hline 2016 & UAE & $\begin{array}{c}\text { United Arab } \\
\text { Emirates (Boeing- } \\
737 \text { ) }\end{array}$ & Lighted up while boarding at the airport & - \\
\hline 2016 & Egypt & $\begin{array}{l}\text { Egypt (Airbus } \\
\text { A320) }\end{array}$ & Crashed near the Greek island of Karpathos & 66 \\
\hline 2016 & Russia & $\begin{array}{c}\text { United Arab } \\
\text { Emirates (Boeing- } \\
737 \text { ) }\end{array}$ & $\begin{array}{l}\text { Bad weather conditions. It crashed while trying to land at } \\
\text { the airport }\end{array}$ & 62 \\
\hline 2015 & Egypt & $\begin{array}{c}\text { Russia (Airbus } \\
\text { A321) }\end{array}$ & A321 disaster over the Sinai Peninsula & 224 \\
\hline 2015 & Indonesia & & Crashed when colliding with a mountain range & 54 \\
\hline 2015 & Indonesia & $\begin{array}{l}\text { Indonesia (ATR 42- } \\
\text { 30) }\end{array}$ & Technical malfunctions. It crashed after takeoff & 116 \\
\hline 2015 & France & $\begin{array}{l}\text { Indonesia (Hercules } \\
\text { C-130) }\end{array}$ & $\begin{array}{l}\text { Sudden loss of altitude. Crashed in the Alps in southern } \\
\text { France }\end{array}$ & 150 \\
\hline 2015 & Syria & $\begin{array}{l}\text { Germany (Airbus } \\
\text { A320) }\end{array}$ & $\begin{array}{c}\text { Front-end bomber of the Su-24M Air Force of the } \\
\text { Russian Federation, which was part of the Russian } \\
\text { aviation group in Syria, was shot down by an air-to-air } \\
\text { missile fired by a F-16C Turkish Air Force fighter near } \\
\text { the Syrian-Turkish border at an altitude of about } 6000 \\
\text { meters, the Syrian province of Latakia in the district of } \\
\text { Baiyirbujak }\end{array}$ & 1 \\
\hline 2014 & Indonesia & $\begin{array}{l}\text { Russia }(\mathrm{Su}-24 \mathrm{M} \\
\text { Front Bomber) }\end{array}$ & Missing on the way from Surabaya to Singapore & 162 \\
\hline 2014 & $\begin{array}{c}\text { Niger } \\
\text { (Sahara) }\end{array}$ & $\begin{array}{l}\text { Indonesia (Airbus } \\
\text { A320-200) }\end{array}$ & & 116 \\
\hline 2014 & Ukraine & $\begin{array}{l}\text { Algeria (McDonnell } \\
\text { Douglas MD-83) }\end{array}$ & Crashed in the Sahara Desert & 298 \\
\hline 2014 & Indian Ocean & $\begin{array}{l}\text { Malaysia (Boeing } \\
777 \text { ) }\end{array}$ & $\begin{array}{l}\text { Terrorist rocket shot down by a ground-to-air class rocket } \\
\text { at an altitude of } 10,000 \mathrm{~km} \text { in the Buk-M1 Donetsk } \\
\text { region }\end{array}$ & 239 \\
\hline 2013 & Ukraine & $\begin{array}{l}\text { Malaysia (Boeing } \\
777-200)\end{array}$ & $\begin{array}{c}\text { On the route from Kuala Lumpur to Beijing, it } \\
\text { disappeared from the control radar }\end{array}$ & 5 \\
\hline 2012 & Indonesia & Ukraine (An-24) & Torn during landing & 45 \\
\hline 2011 & Indonesia & $\begin{array}{c}\text { Indonesia (CASA } \\
\text { C-212) }\end{array}$ & It disappeared from the radar and crashed & 18 \\
\hline 2011 & Morocco & $\begin{array}{l}\text { Morocco (Lockheed } \\
\text { C-130 Hercules) }\end{array}$ & He crashed into Imstitan Mountain during landing & 78 \\
\hline 2011 & Congo & Georgia (CRJ-100) & $\begin{array}{l}\text { During landing in bad weather conditions, the plane hit } \\
\text { the runway, split into two and caught fire }\end{array}$ & 32 \\
\hline 2010 & Cuba & $\begin{array}{c}\text { Cuba (ATR-72- } \\
212 \text { ) }\end{array}$ & Crashed near Sancti Spiritus in the center of Cuba & 68 \\
\hline 2010 & China & China (E-90) & Crashed during landing & 42 \\
\hline 2010 & India & $\begin{array}{l}\text { India (Boeing } 737- \\
800)\end{array}$ & $\begin{array}{l}\text { Rolled off the runway. Punching the fence, the plane } \\
\text { broke into two parts, rolled along a forested slope and } \\
\text { caught fire }\end{array}$ & 158 \\
\hline 2010 & Libya & $\begin{array}{c}\text { Ethiopia (Boeing } \\
737 \text { ) }\end{array}$ & $\begin{array}{c}\text { Crew error, climb. Has experienced accidents over the } \\
\text { Mediterranean Sea. }\end{array}$ & 90 \\
\hline
\end{tabular}


Table 2. Earthquakes, fires, floods, hurricanes.

\begin{tabular}{|c|c|c|}
\hline Year & Natural disasters & Place \\
\hline $\begin{array}{c}\text { July, August, September } \\
2018\end{array}$ & Earthquakes & Indonesia: Lombok, Sulawesi and Bali \\
\hline September 2018 & Earthquakes & Japan: Hokkaido Island \\
\hline October 2018 & Earthquakes & Haiti \\
\hline November 2018 & Fires & California, USA \\
\hline July 2018 & Fires & Greece \\
\hline October 2018 & Floods & Italy and France: Sicily, Sardinia, France \\
\hline $\begin{array}{c}\text { September, October } \\
2018\end{array}$ & $\begin{array}{c}\text { Hurricanes Michael and } \\
\text { Florence }\end{array}$ & USA \\
\hline October 2018 & Flood "Leslie" & Portugal \\
\hline September 2018 & Jeb's Typhoons & Japan \\
\hline June 2018 & Fuego Volcano Eruption & Guatemala \\
\hline May 2018 & Kilauea Volcano Eruption & Hawaii \\
\hline Summer 2018 & Showers & Ukraine: Kiev, Lviv, Odessa \\
\hline January 2017 & Abnormal frosts & $\begin{array}{c}\text { European countries (Poland, Czech } \\
\text { Republic, Italy, Germany, Ukraine and } \\
\text { others), Balkans, Turkey, Russian } \\
\text { Federation }\end{array}$ \\
\hline January 2017 & $\begin{array}{c}\text { A series of earthquakes in } \\
\text { Italy }\end{array}$ & Montereal, Central Italy \\
\hline July 2017 & Forest fires in Canada & Provinces of British Columbia, Canada \\
\hline July-September 2017 & Flooding in Asia & India, Bangladesh, Nepal, Pakistan \\
\hline $\begin{array}{c}\text { August } 17 \text { - September } \\
\text { 3, } 2017\end{array}$ & Hurricane Harvey & $\begin{array}{c}\text { Guyana, Nicaragua, Honduras, Belize, } \\
\text { Cayman Islands, Yucatan Peninsula, USA } \\
\text { - Largest Louisiana in Texas }\end{array}$ \\
\hline $\begin{array}{c}\text { August } 30 \text { - September } \\
16,2017\end{array}$ & Hurricane Irma & $\begin{array}{c}\text { Cape Verde, St. Martin, US Virgin } \\
\text { Islands, Cuba, Puerto Rico, Bahamas, } \\
\text { USA - especially Florida }\end{array}$ \\
\hline $\begin{array}{l}\text { October, December } \\
2017\end{array}$ & Forest fires in California & California, USA \\
\hline November 2017 & Typhoon Damry & $\begin{array}{l}\text { Vietnam, Hong Kong, Philippines, } \\
\text { Cambodia, Thailand }\end{array}$ \\
\hline $\begin{array}{c}\text { November } 29- \\
\text { December 6, } 2017\end{array}$ & Otshi Cyclone & Sri Lanka, Southern India, Maldives \\
\hline
\end{tabular}

Table 3. Marine disasters.

\begin{tabular}{|c|c|c|}
\hline Year & Marine disaster & Place \\
\hline 2018 & Sank the ferry & Off the coast of Indonesia, the sunken steam \\
\hline 2018 & $\begin{array}{c}\text { Sank a boat with illegal migrants in } \\
\text { the Mediterranean }\end{array}$ & Off the coast of Tunisia \\
\hline 2017 & The ship sank & Congo \\
\hline 2017 & $\begin{array}{c}\text { Sank a boat with illegal migrants in } \\
\text { the Mediterranean }\end{array}$ & Illegal migrants from Libya \\
\hline 2017 & $\begin{array}{c}\text { A cruise ship sank near Mykonos } \\
\text { Island }\end{array}$ & $\begin{array}{c}\text { Greece } \\
\text { Giglio }\end{array}$ \\
\hline 2012 & $\begin{array}{c}\text { The collapse of the Costa Concordia } \\
\text { cruise ship }\end{array}$ & in the Tyrrhenian Sea near the Italian island of \\
\hline
\end{tabular}


Table 4. Terrorism.

\begin{tabular}{|c|c|c|c|}
\hline Date & What happened & Where & Killed \\
\hline $\begin{array}{l}\text { April 15, } \\
2013\end{array}$ & $\begin{array}{l}\text { In Boston, during the annual marathon, two } \\
\text { explosions occurred near the finish line }\end{array}$ & USA & $\begin{array}{c}3 \text { dead, } \\
\text { over } 280 \\
\text { injured }\end{array}$ \\
\hline $\begin{array}{l}\text { April 2, } \\
2015\end{array}$ & $\begin{array}{l}\text { In the Kenyan city of Harris, terrorists attacked a } \\
\text { university where mostly Christians were killed }\end{array}$ & Kenya & $\begin{array}{l}147 \text { people } \\
\text { were killed, }\end{array}$ \\
\hline $\begin{array}{l}\text { July } 17, \\
2014\end{array}$ & $\begin{array}{c}\text { In the territory of Donetsk region occupied by } \\
\text { pro-Russian fighters, a passenger Boeing } 777 \text { was } \\
\text { shot down, flying from Amsterdam to Kuala } \\
\text { Lumpur }\end{array}$ & Ukraine & $\begin{array}{l}80 \text { were } \\
\text { injured }\end{array}$ \\
\hline $\begin{array}{l}\text { June 26, } \\
2015\end{array}$ & $\begin{array}{l}\text { Terrorists attack hotel beach in Port El Kantaoui, } \\
\text { a suburb of Sousse resort, where they started } \\
\text { shooting at tourists from two hotels }\end{array}$ & Tunisia & $\begin{array}{c}283 \\
\text { passengers } \\
\text { and } 15 \text { crew } \\
\text { members }\end{array}$ \\
\hline $\begin{array}{c}\text { January } 7, \\
2015\end{array}$ & Attack on the editorial board of Cherlie Hebdo & France & 40 \\
\hline $\begin{array}{l}\text { March 18, } \\
2015\end{array}$ & Attack on tourists & Tunisia & 12 \\
\hline $\begin{array}{l}\text { March 20, } \\
2015\end{array}$ & The explosion in the Badr mosque & Yemen & 23 \\
\hline $\begin{array}{l}\text { June } 26 \\
2015\end{array}$ & Attack on a tourist hotel & Tunisia & 130 \\
\hline $\begin{array}{l}\text { October } \\
10,2015\end{array}$ & Explosions in Ankara & Turkey & 37 \\
\hline $\begin{array}{l}\text { October } \\
31,2015\end{array}$ & The crash of the Russian plane & Sinai Peninsula & 95 \\
\hline $\begin{array}{l}\text { November } \\
14,2015\end{array}$ & A series of terrorist attacks in Paris & France & 224 \\
\hline $\begin{array}{l}\text { November } \\
20,2015\end{array}$ & Attack on the hotel & Mali & 140 \\
\hline $\begin{array}{l}\text { March 13, } \\
2016\end{array}$ & An explosion in Ankara & Turkey & 19 \\
\hline $\begin{array}{l}\text { March 22, } \\
2016\end{array}$ & Explosions at Brussels Airport & Belgium & 37 \\
\hline $\begin{array}{l}\text { June } 28 \\
2016\end{array}$ & Explosions at Istanbul Airport & Turkey & 26 \\
\hline $\begin{array}{l}\text { July 14, } \\
2016\end{array}$ & A terrorist attack on the waterfront of Nice & France & 41 \\
\hline
\end{tabular}

international tourist flows to Egypt

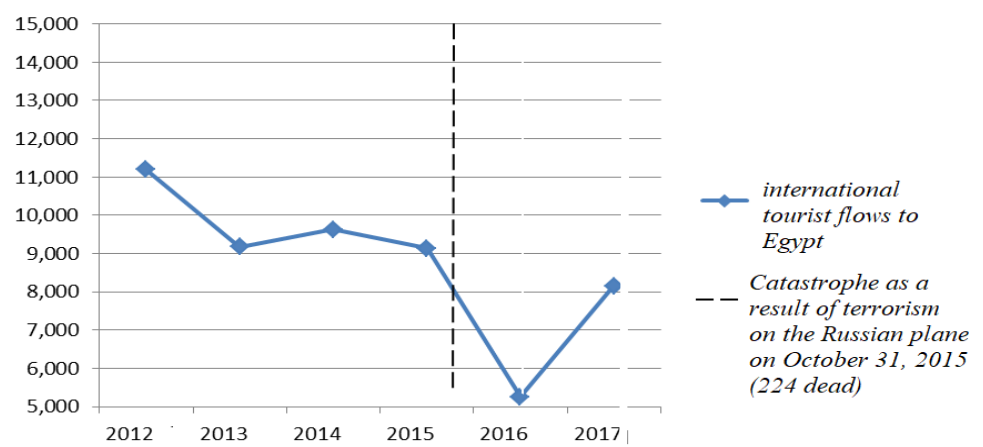

Fig. 1. International tourist flows to Egypt. 


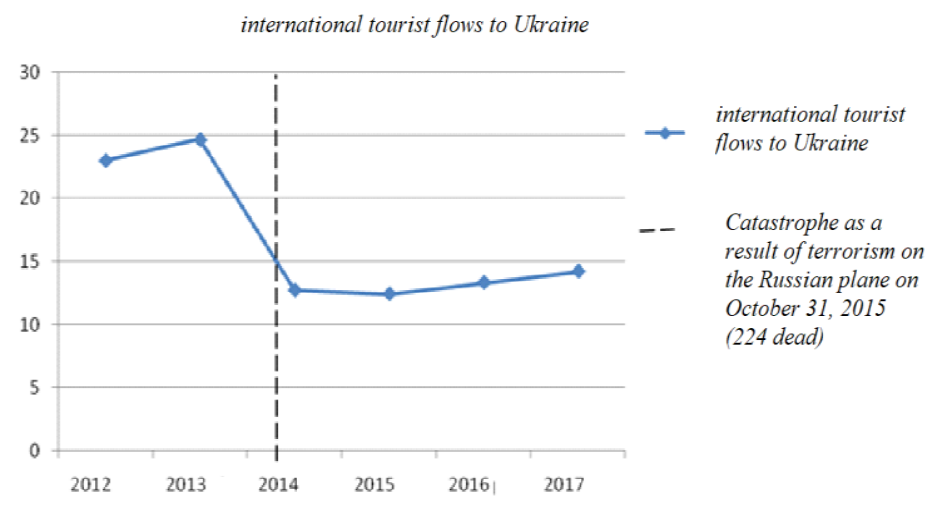

Fig. 2. International tourist flows to Ukraine.

International tourist flows to Turkey

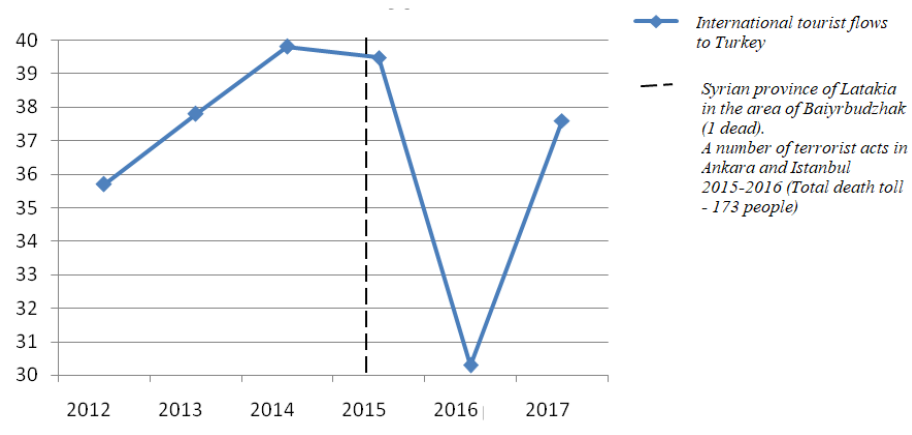

Fig. 3. International tourist flows to Turkey.

Tourism flows in this area have increased almost twice on average every two years. And the system of interstate regulation is not able to quickly adapt to the rapidly changing situation in the tourism sphere. Financial flows were almost out of control of national countries.

The modern world tourist system has become virtually independent of state control and regulation.

Travel flows and related currency exports are reflected negatively in the country's balance of payments and positively on the balance of the host country. According to the directions of the currency movement, for the country sending its resident abroad, the tourist expenses are import, and for the host country - export. From the static [1,2], we see that the main balance of payments deficits are in the underdeveloped developing countries; including Ukraine. Imports of services in Ukraine (tourism expenditures) are almost three times higher than exports of services from Ukraine (revenues from international tourism) according to the WTO. Balance of payments is negative. That is, Ukraine, with its great tourist potential, is a donor country, tourist supplier to countries such as Turkey, Poland, Egypt, Croatia, Montenegro and others.

The main indicators of the study of the tourist market and its subjects should include those that adequately and promptly reflect the main changes, trends and rates of market development and are least affected by random, uncontrolled and difficult to predict factors. 
As you know, the economy develops under the influence of the following factors: physical, psychological, political, economic, social origin; locally, nationally or globally; clear and not quite clear in character and expression; temporary and lasting in effect.

While exploring the main indicators of the tourism market research, you may be faced with a dilemma: on the one hand, you should use as many indicators as possible in order to have a better, detailed, adequate analysis of the situation and to identify the factors that are shaping and developing.

But on the other hand, the number of indicators selected should be minimized within a reasonable range, since it is practically impossible to find extremely voluminous information material that adequately reflects the situation in a short period of time; systematize it, analyze and identify trends and make the necessary forecast.

This is due to the fact that due to the excessive number of characteristics, it is impossible to analyze them all at the same time, that is, when the last ones are put into order - the former may change and no longer be true, so they will have to be supplemented, refined in order not to nullify all the accomplishments. work.

Thus, from a large number of possible indicators, it is necessary to select the most important ones that best reflect the influence of economic factors, that is, those characteristics that shape the current situation and will take place in the near future, namely internal and external factors influencing tourist flows.

Internal factors influencing tourist flows include the following:

- Cost of tourist services;

- Convenience of flight data (place of departure, duration of flight, airline reliability);

- Benefits in relation to the type of recreation (food system, municipal or private beaches, mountainous or deserted areas);

- Health status and climatic conditions in the chosen direction of tourist travel (seasonality in different countries);

- Presence or absence of a visa. In case of complexity and cost of paperwork;

- Political and economic situation in the chosen direction of tourist travel.

External factors influencing tourist flows are determined by events of anthropogenicmilitary nature, namely natural disasters, terrorist activity, aviation, maritime and other catastrophes.

Despite the realities of the country's economy, the tourism industry in Ukraine is dynamically developing. During the period 2007-2018, the development of the tourism industry was influenced by investments, which were heavily channeled into the hotel and restaurant sectors. Investments increased from UAH 469 to 4908 million, or 10.5 times [6, p. 204], although most experts, including representatives of the Ministry of Culture and Tourism of Ukraine [15], believe that the tourism infrastructure of the country is underdeveloped and morally obsolete.

It is also worth pointing out that domestic tourist flows by $71.1 \%$ were provided by inbound tourist flows and only by $28.9 \%$ by domestic tourists, and during 2007-2018 the share of domestic tourists on the market tended to decrease, may indicate a weak development of domestic tourism in Ukraine (Fig. 4).

At the same time, official statistics from different sources differ significantly, which is caused by, on the one hand, different methodological accounting bases and, on the other, by significant shadow turnover in the industry. It is impossible to determine the capacity of the tourist of flows market today. 


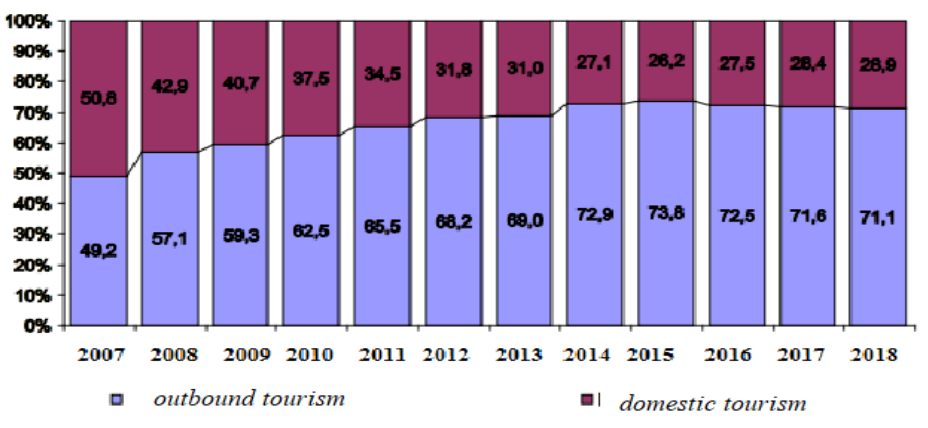

Fig. 4. Dynamics of the structure of domestic tourist flows in Ukraine from 2007 to 2018 [15].

According to the State Service for Tourism and Resorts, the amount of consumption secured by tourist flows is about $\$ 3.8$ billion. Per is year (of which only $\$ 1.1$ billion falls on licensed market operators) [11, p. 3].

Statistics of Ukraine do not consider the tourism industry as a complex economic complex and evaluate its individual components according to the spheres of economic activity according to the NACE codes.

Statistics on tourism development in Ukraine often contain considerable controversy and controversy. According to official statistics, in 2018 the activity of sectors serving mainly tourist flows amounted to about $\$ 5.4$ billion. USA [15].

At the same time, the UNWTO World Tourism Organization estimated Ukraine's tourism flows in 2018 at $\$ 3.8$ billion. USA [14, p. 7], and the World Economic Forum estimated total tourism revenue in Ukraine in 2018 at $\$ 2.2$ billion. USA [11, p. 368]. According to experts from the US Agency for International Development USAID, the average foreign tourist stays in Ukraine for about 4 days, leaving about $\$ 600$ during this time. USA [8, p. 154], which of corresponds to revenues from tourism activities of $\$ 12.7$ 12.8 billion. USA.

Despite the significant positive changes in the tourism sector, the significant increase in tourist flows and revenues from tourism activities, it should be noted that the dynamics of the industry in Ukraine is far behind the global trends. According to the State Statistics Service [13], in the last 10 years the dynamics of inbound tourism development in Ukraine has averaged $12.6 \%$ per year.

However, the global financial crisis has significantly affected the trend of inbound flows; in 2009 the flow of foreign tourists decreased by $18.3 \%$ according to the State Statistics Service [12] and 24\% according to the Ministry of Culture and Tourism of Ukraine [12].

The reason for such negative dynamics of the Ukrainian tourism sphere is the lack of promotion of tourism products in the world market. This is evidenced by the structure of inbound tourist flows in Ukraine. In 2017-2018, 89.6\% of all arriving tourists visited Ukraine for a private purpose, namely: $5.7 \%$ of tourists intended to visit tourists (Table 5).

In 2018 , about $74.1 \%$ of foreign tourists came to Ukraine for leisure and recreation, which necessitates the development of appropriate tourism infrastructure.

Almost $18.4 \%$ of tourists came to Ukraine for business purposes, so it is important to improve business tourism infrastructure. On the other hand, the share of medical tourism in recent years has tended to decrease and in 2017 was only $5.8 \%$ of the total inbound tourist flow, which confirms the assumption about the negative state of the spa sphere in Ukraine (Fig. 5). 
Table 5. Structure of tourist flows by purpose of visit in 2018 [15]

\begin{tabular}{|c|c|c|}
\hline goal & number of people & part,\% \\
\hline official, business & 644992 & 3.01 \\
\hline tourism & 1225954 & 5.72 \\
\hline private & 19180171 & 89.56 \\
\hline teaching & 59169 & 0.28 \\
\hline employment & 16143 & 0.08 \\
\hline immigration (permanent residence) & 64796 & 0.3 \\
\hline $\begin{array}{c}\text { cultural and sports exchange, } \\
\text { religious, other }\end{array}$ & 224071 & 1,05 \\
\hline
\end{tabular}
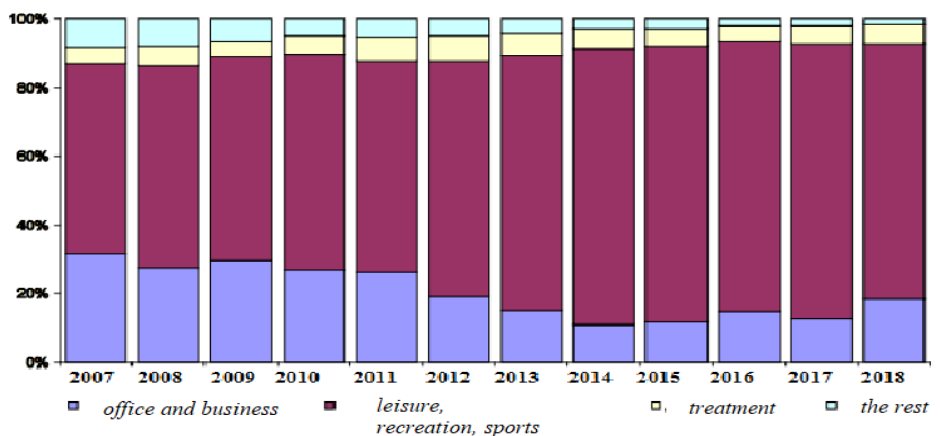

Fig. 5. Structure of tourist flows by purpose of travel during 2007-2018 [15].

The development of the tourist services market depends on a sufficient number of licensed participants, the share of which remains small today. Of all the operators licensed to operate in the tourism business, in fact, only $66.0 \%$ work.

The share of licensed operators in servicing domestic tourist flows in the last decade has decreased from $26.9 \%$ in 2007 to $4.4 \%$ in 2018 , which only confirms the importance of improving tourism infrastructure in Ukraine (Fig. 6).

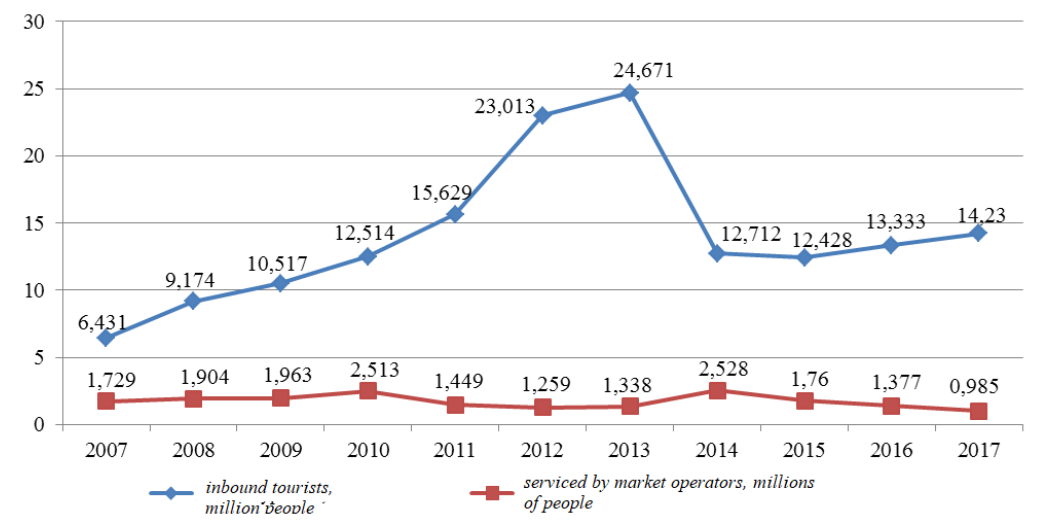

Fig. 6. Comparison of inbound tourism flows for the period 2007-2018 [16].

In today's context, it is difficult to identify all-Ukrainian tendencies in the dynamics of domestic tourist flows in Ukraine, which can testify to the significant influence of regional features on the competitiveness of a region and the formation of tourist flows at the regional level. The development of the tourism sphere of this or that region contributes to the formation of a sustainable tourist flow. However, the increase in tourist flow raises the problem of determining the optimal environmental load for the region and the need to 
determine the maximum capacity without sacrificing the environment and historical and cultural heritage. This issue is being actively discussed by scholars in the context of sustainable tourism development, the aim of which is a harmonious combination of economic activity, the conservation of natural ecosystems and the enhancement of social welfare [15, p. 106].

The planning of work in any sphere of economic activity is based on forecasting the results. Indeed, forecasting is the definition of trends and prospects for the development of certain processes, based on the analysis of their previous states [1].

Depending on the forecasting period, forecasts are divided into short-term (up to three months), medium-term (up to two-three years) and long-term (more than two-three) years.

When selecting forecasting methods, one should be aware that some of the methods require a large amount of initial data - quantitative methods, while others work in general without reliable information, based, for example, on the expertise of experts - qualitative methods.

With the fundamental difference between qualitative and quantitative forecasting methods, they are based on the same principles and assumptions, namely:

- All methods require qualitative or quantitative analysis of past periods;

- Forecasts are rarely accurate; they can only indicate the trend of development;

- The accuracy of the prediction is inversely proportional to the prediction interval (the higher the horizon, the less the accuracy);

- Forecasts for the industry, direction, and complex are generally more accurate than forecasts for individual enterprises, parameters, etc.

We need to realize that the iterative procedure for constructing a mathematical prediction model is based on:

- Identification - the use of any information on how the numerical values under study have been obtained in order to select a set of economic parameters that deserve attention;

- Evaluation - obtaining model parameters that determine its adequacy;

- Diagnostic verification - Checking the consistency of the model with the initial data.

The application of any quantitative methods requires extensive preparation: collection, analysis, statistical processing of data.

We use the concept of time trend - the main trend of changing the time series. Forecasting economic indicators based on trend models is based on extrapolation as a method of scientific forecasting [13-15].

In the context of the study problem, by extrapolation, we understand the extension of the laws that they established during the study period beyond.

The reliability of constructing long-term forecasts requires us to use, analyze, compare several methods; defining their advantages and disadvantages [14]. We will illustrate in detail the application of all selected methods.

The simple moving average method [13] is that the calculation of an indicator at a predicted point in time is based on obtaining averages of this indicator over several previous points,

$$
f_{k}=\frac{\sum_{k-1-N}^{k-1} x_{i}}{N}
$$

Here $f_{k} \quad$ is the value of the indicator according to the forecast, $x_{i}$ - previous (experimentally obtained) metric values, ${ }^{N}$ the magnitude of the smoothing interval. In the presented calculations accepted $N=3$ and expanded the forecast horizon by using precalculated metrics. 
The advantages of the presented method include the ease of use and the clarity of the results obtained. The significant disadvantage is the fact that with a small number of observations, the magnitude of the smoothing interval affects the shape of the trend; the initial and final elements of the series are lost.

The weighted moving average [13-15] method is based on the fact that the impact of all real indicators used in the calculations is not the same, more recent data is usually more influential. This introduces the notion of "weight" of each of the indicators: older data have less weight, more recent - more. Mathematically, this method can be described by the formula:

$$
f_{k}=\sum_{i=1}^{N} \omega_{k-i} \cdot x_{k-i}
$$

Note that the value of "weight" is always a value that is positive and satisfies the condition.

$$
0 \leq \omega_{k} \leq 1
$$

In calculations, we also take $N=3 \mathrm{i} \omega_{1}=0,1, \omega_{2}=0,3, \omega_{3}=0,6$ (these weights are used most often). Note that a numerical experiment was conducted with other values of the weights. As a result, we made sure that the selected weights give the most favorable indicators. The results of the calculations are summarized in the table:

The proposed method of refinement is based on the feedback method: new forecasts are made taking into account adjustments to previous ones. When choosing weights, you also need to consider the feedback. The advantage of the method in taking into account the objective disparity of the "old" and "new" data is undoubted with a small forecast horizon (in our case - 1 year).

Trend projection method. The basic idea of this [13-15] method is to construct a line that "deviates" on average the least from the array of points set by the trend. To reflect the underlying trend, changes in metrics use any function, but most often with polynomials:

- $f_{k}=a_{0}+a_{1} \cdot t$ - polynomial of the first degree;

- $f_{k}=a_{0}+a_{1} \cdot t+a_{2} \cdot t^{2}$ - second degree polynomial;

- $f_{k}=a_{0}+a_{1} \cdot t+a_{2} \cdot t^{2}+\cdots+a_{n} \cdot t^{n}$ - Polynomial of the $n$ degree.

Here $a_{0}, a_{1}, a_{2}, \ldots$ - the parameters of the polynomials. In statistical practice, they have their own interpretation: $a_{0}$ it characterizes the average conditions for the development of a number of dynamics of a parameter, $a_{1}$ - his rate of growth (falling, at negative values), $a_{2}$ - the acceleration of growth (falling). The values of the polynomial parameters are found by the least squares method. Its essence is to determine such coefficients for which the sum of the squares of deviations of the calculated values from the actual would be minimal. Thus, these coefficients find expression minimization

$$
\sum_{i=1}^{N}\left(x_{i}-f_{i}\right)^{2} \rightarrow \min
$$

Here $N$ - number of row elements, $x_{i}$ - the actual value of the parameter, $f_{i}$ - calculated value. As a result of minimization, a system of normal equations is obtained:

$$
\left\{\begin{array}{c}
n \cdot a_{0}+a_{1} \sum_{i} t_{i}+a_{2} \sum_{i} t_{i}^{2}+\cdots+a_{n} \sum_{i} t_{i}^{n}=\sum_{i} x_{i} \\
a_{0} \sum_{i} t_{i}+a_{1} \sum_{i} t_{i}^{2}+a_{2} \sum_{i} t_{i}^{3}+\cdots+a_{n} \sum_{i} t_{i}^{n+1}=\sum_{i} x_{i} \cdot t_{i} \\
a_{0} \sum_{i} t_{i}^{n}+a_{1} \sum_{i} t_{i}^{n+1}+a_{2} \sum_{i} t_{i}^{n+2}+\cdots+a_{n} \sum_{i} t_{i}^{2 n}=\sum_{i} x_{i} \cdot t_{i}^{n}
\end{array}\right.
$$

We performed the design using a linear (1st degree polynomial) trend (Table 6, Fig. 7 9). 
Table 6. Number of foreign tourists, thousand

\begin{tabular}{|c|c|c|c|}
\hline Period & Turkey & Ukraine & Egypt \\
\hline 2012 & 35,698 & 23013 & 11196 \\
\hline 2013 & 37,795 & 24671 & 9174 \\
\hline 2014 & 39,811 & 12712 & 9628 \\
\hline 2015 & 39,478 & 12428 & 9139 \\
\hline 2016 & 30,289 & 13333 & 5258 \\
\hline 2017 & 37,601 & 14230 & 8157 \\
\hline
\end{tabular}

the number of foreign tourists in Turkey

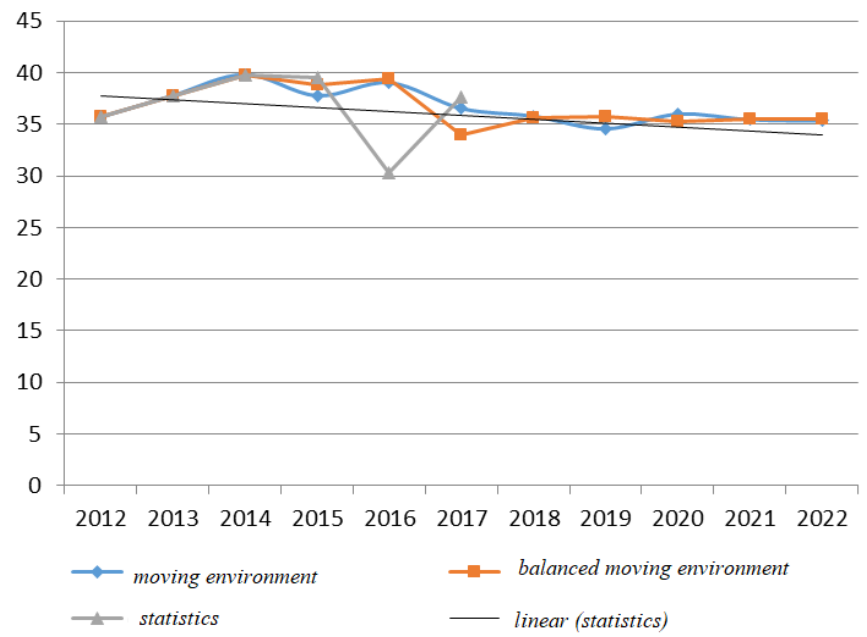

Fig. 7. Forecast of the number of foreign tourists in Turkey.

\section{number of foreign tourists in Ukraine}

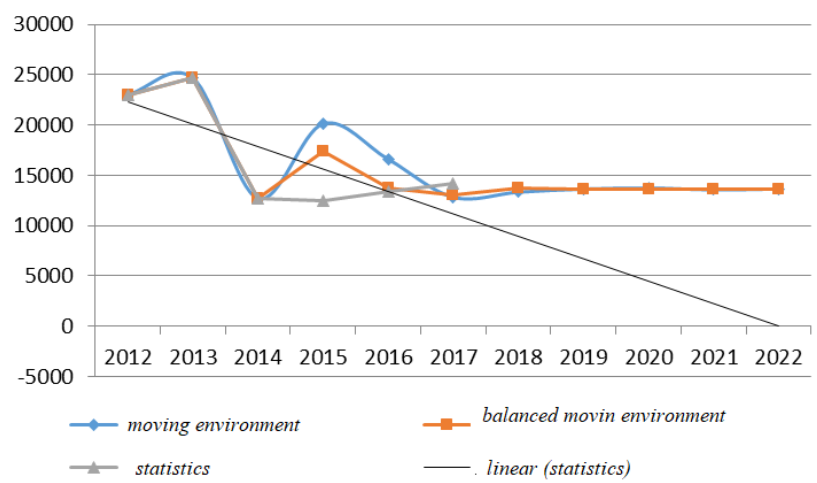

Fig. 8. Forecast of the number of foreign tourists in Ukraine. 
the number of foreign tourists in Egypt

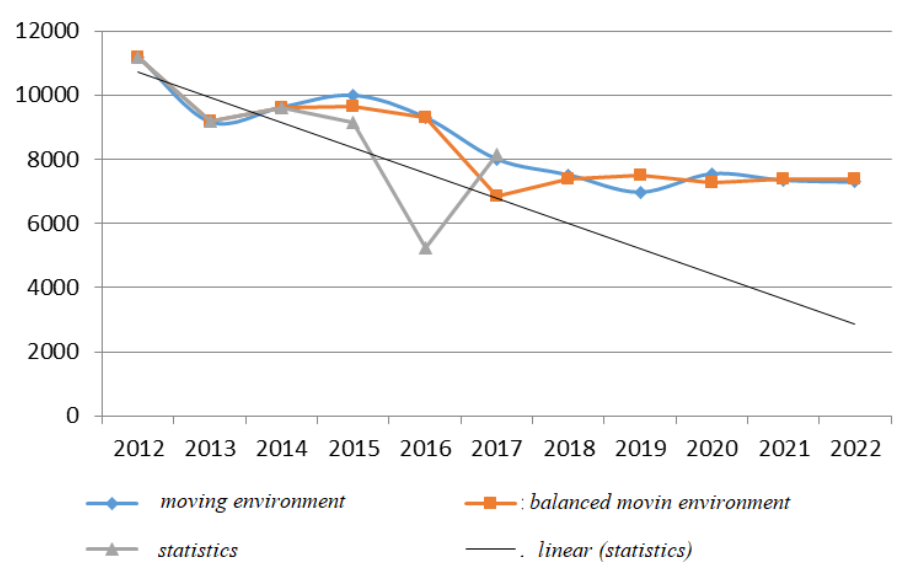

Fig. 9. Forecast of the number of foreign tourists in Egypt.

Graphically linear trend is represented by a straight line. In this case, there are ascending, descending and lateral trends. The upward trend is described as a line of "support" and the downward trend - as a line of "resistance".

\section{Conclusions}

Conclusion. The tourism business is of great importance for any country in the world because of its powerful opportunities for attracting significant financial income, promoting the infrastructural development of the territories and increasing the employment of the local population, the use of free geographical, natural and climatic, recreational resources, ensuring synergistic effect within the organic combination of tourism spheres with other branches of national economies. But today tour operators feel a significant negative impact of natural and man-made factors on the formation and redistribution of tourist flows. The author analyzes the impact of aviation and maritime catastrophes, earthquakes, fires, floods, hurricanes, the effects of terrorism on tourist flows to Egypt, Turkey, and Ukraine and concludes that these events caused a significant reduction in the number of tourists arriving to tourists and redirecting tourists to the tourist destinations, countries.

The study found that the Ukrainian tourism industry is characterized by negative dynamics, and therefore, the country annually underperforms a large amount of foreign exchange financial revenues, and tour operators do not withstand competition and are forced to leave the market. In view of this, the author proposes a mechanism for predicting the volume of tourist flows based on the use of mathematical modeling, which will allow to take into account the scale of the crisis, its terms, development and distribution in order to improve the activities of the crisis in the event of crisis caused by natural and technological factors in one or another tourist direction and ensuring their stable functioning under conditions of destabilizing factors.

\section{References}

1. L.G. Agafonova, Turizm, gotelnij ta restorannij biznes: cinoutvorennya, konkurenciya, derzhavne regulyuvannya (Znannya Ukrayini, Kiyv, 2002) 
2. O.M. Azaryan, Zhukova, Rinok turistichnih poslug: monitoring i rozvitok kompleksu marketing (DonMU, Doneck, 2002)

3. M.P. Bondarenko, Ekonomika i prognozuvannya, 1, 104-119 (2011)

4. I.I. Butko, I. I. Turisticheskij biznes: osnovy organizacii (Feniks, Rostov n/D, 2008)

5. State statistics: Derzhavna sluzhba statistiki [Elektronnij resurs]. http://www.ukrstat.gov.ua

6. V.V. Druzhinina, Ekonomika i suspilstvo, 15, 528-534 (2018)

7. L.P. Dyadechko, Ekonomika turistichnogo biznesu (Centr navch. 1-ri, Kyiv, 2007)

8. M.A. Zhukova, Industriya turizma: menedzhment organizacij (Finansy i statistika, Moscow, 2006)

9. V.F. Kifyak, Organizaciya turistichnoyi diyalnosti v Ukrayini (Knigi - XXI, Chernivci, 2003)

10. O.O. Lyubiceva, Rinok turistichnih poslug (Alterpres, Kyiv, 2005)

11. I.I. Kovtunik, Visnik Kam'yanec-Podilskogo nacionalnogo universitetu imeni Ivana Ogiyenka: Ekonomichni nauki, 8, 303-305 (2013) http://irbisnbuv.gov.ua/UJRN/vkpnuen_2013_8_84.pdf

12. I.M. Pisarevskij, Ekonomichnij prostir, 102, 83-93 (2015)

13. I.M. Pisarevskij, S.O. Pogasij, M.M. Pokolodna, Organizaciya turizmu (HNAMG, 2008)

14. O.O. Komlichenko, Naukovij visnik Hersonskogo derzhavnogo universitetu. Seriya Ekonomichni nauki, 8(3), 75-79 (2014)

15. T.I. Tkachenko, Stalij rozvitok turizmu: teoriya, metodologiya, realiyi biznesu (Kiyiv. nac. torg-ekon. un-t, Kyiv, 2009) 